\title{
Fluorescent Spot Test
}

National Cancer Institute

\section{Source}

National Cancer Institute. Fluorescent Spot Test. NCI Thesaurus. Code C132427.

A method to assess enzymatic activity in which a substrate reagent is incubated with a biological specimen and spotted on filter paper. The spots are then examined for fluorescence, which correlates with enzyme activity. 